\title{
TEORI KEPUASAN KONSUMEN
}

\section{Makalah Ini Disusun untuk Memenuhi Tugas Kelompok pada Mata Kuliah Ekonomi Mikro Islam}

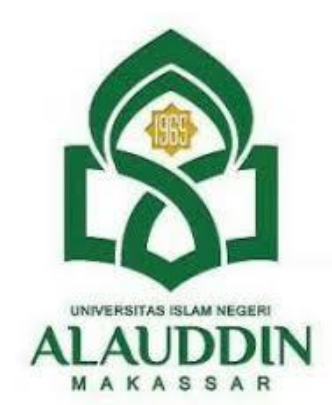

KELOMPOK 4 :

Muthmainnah

(90500120023)

Intan Nurul Wahidah (90500120036)

Muh. Afta Noer

(90500120033)

Rahmayani Ahmad (9050012s0043)

\author{
PERBANKAN SYARIAH \\ FAKULTAS EKONOMI DAN BISNIS ISLAM \\ UNIVERSITAS ISLAM NEGERI ALAUDDIN MAKASSAR \\ TAHUN 2021
}




\begin{abstract}
ABSTRAK
Seiring dengan perkembangan ilmu pengetahuan dan teknologi, konsep pemasaran modern pun mengalami perkembangan dengan menempatkan konsumen sebagai perhatian utama. Masalah kepuasan konsumen menjadi semakin kompleks karena perusahaan perlu memperhatikan aspek-aspek lain yang ada. Dimana Pada dasarnya tujuan dari suatu bisnis adalah untuk memperoleh laba yang besar dan juga menciptakan konsumen yang puas. kepuasan konsumen adalah situasi kognitif pembeli berkenaan dengan kesepadanan atau ketidaksepadanan antara hasil yang di dapatkan di bandingkan dengan pengorbanan yang di lakukan. Beberapa hal dalam cakupan teori kepuasan konsumen ini diantaranya preferensi konsumen, penganalisis kurva indeverensi, garis anggaran, solusi optimal dan prespektif Islam terhadap kepuasan konsumen. Preferensi juga diartikan sebagai pilihan suka atau tidak suka oleh seseorang terhadap suatu produk, barang atau jasa yang dikonsumsi dimana Garis anggaran (budget line), yang berfungsi menghubungkan titik-titik kombinasi barang yang dapat dibeli dengan sejumlah pendapatan tertentu dengan demikian, Kombinasi konsumsi yang dapat memberikan kepuasan konsumen secara maksimal yang merupakan optimalitas atau titik optimal bagi konsumen. Selain itu Kepuasan dalam Islam berkaitan dengan keimanan yang melahirkan rasa syukur atas kenikmatan yang didapatkan. Dengan mengetahui teori kepuasan diharapkan perekonomian dapat merata diseluruh masyarakat sehingga menciptakan kesejahteraan hidup.
\end{abstract}

Kata kunci: Teori, Kepuasan, Konsumen. 


\section{KATA PENGANTAR}

Assalamu'alaikum $W r$. Wb

Puji syukur dipanjatkan kehadirat Allah SWT, atas limpahan rahmat dan karunia-Nya saya dapat menyelesaikan penyusunan makalah yang berjudul "Teori Kepuasan Konsumen" ini dengan baik meskipun banyak kekurangan didalamnya. Shalawat serta salam tetap tercurahkan kepada Nabi Muhammad SAW., kepada keluarganya, para sahabatnya, serta kepada kita sebagai umat akhir zaman.

Adapun tujuan dari penulisan dari makalah ini adalah untuk memenuhi tugas kelompok pada mata kuliah Ekonomi Mikro Islam. Selain itu, makalah ini juga bertujuan untuk menambah wawasan bagi para pembaca dan penulis. Saya mengucapkan terimakasih kepada bapak Samsul Arifai, S.A.B., M.A selaku Dosen Pengampu mata kuliah Ekonomi Mikro Syariah yang telah memberikan tugas ini. Saya juga mengucapkan terimahkasih kepada semua pihak yang telah membagi sebagian pengetahuannya sehingga saya dapat menyelesaikan makalah ini.

Dalam penyusunan makalah ini saya menyadari bahwa masih banyak kekurangan atau kesalahan yang mungkin harus diperbaiki. Oleh karena itu, saya mohon maaf atas kekurangan dan kesalahan tersebut. Kritik dan saran kepada saya sangat diharapkan untuk membangun dan menunjang kesempurnaan makalah.

Wassalamu'alaikum Wr. Wb

Gowa, 7 Oktober 2021

Penulis 


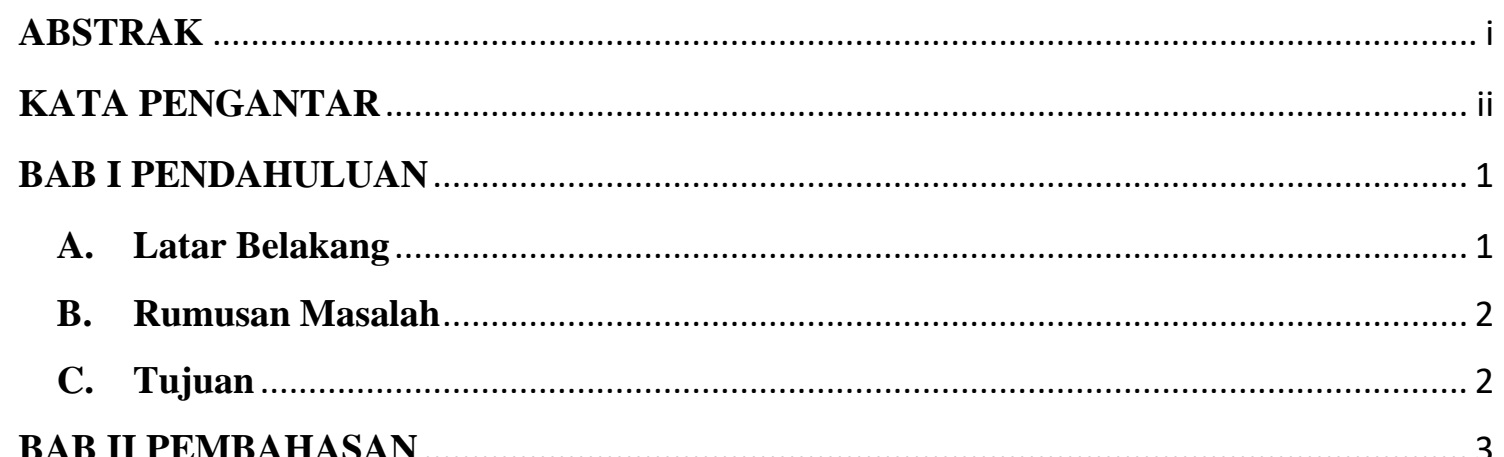

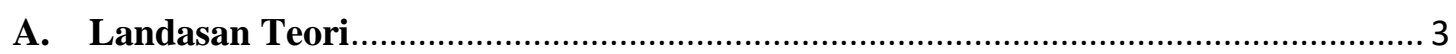

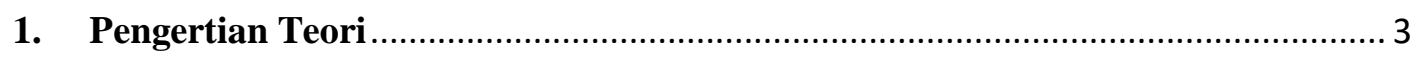

2. Pengertian Kepuasan Konsumen............................................................... 3

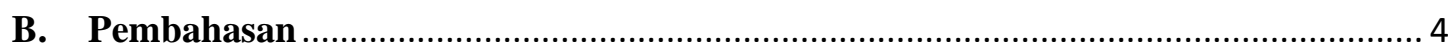

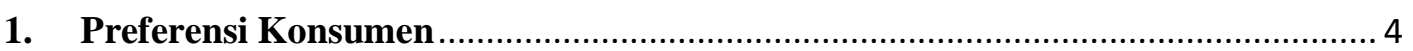

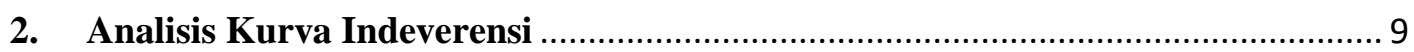

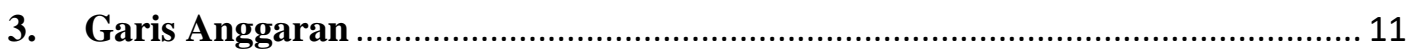

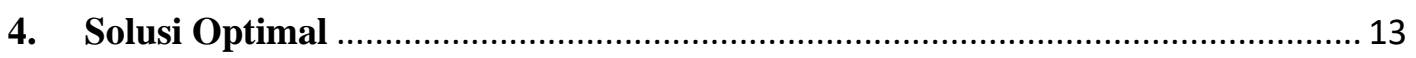

5. Prespektif Islam Terhadap Kepuasan Konsumen .......................................... 15

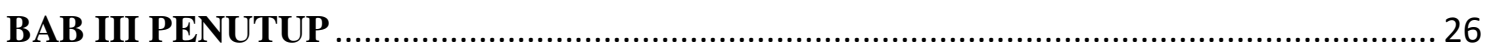

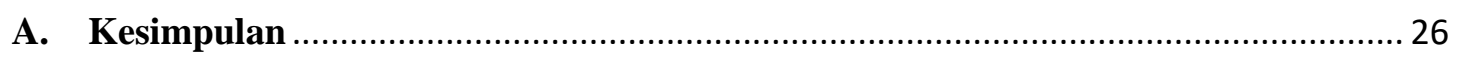

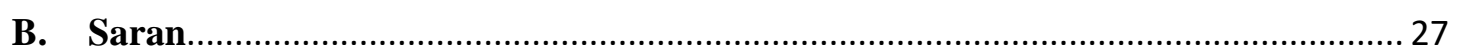

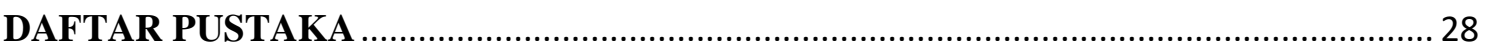




\section{BAB I \\ PENDAHULUAN}

\section{A. Latar Belakang}

Seiring dengan perkembangan ilmu pengetahuan dan teknologi, konsep pemasaran modern pun mengalami perkembangan dengan menempatkan konsumen sebagai perhatian utama. Produsen berlomba-lomba untuk sebisa mungkin dapat bersaing dengan kompetitor. Kualitas produk merupakan salah satu faktor yang mempengaruhi kepuasan konsumen. Kualitas produk ditentukan oleh sekumpulan kegunaan dan fungsinya, termasuk kinerja/ performance, daya tahan, kesesuaian dengan spesifikasi, estetika produk, dan juga perceived quality/ kesan produk. Konsumen pun bersikap lebih selektif dan kritis dalam memilih produk yang akan dibeli. Produk dengan kualitas yang bagus dan terpercaya akan senantiasa tertanam dibenak konsumen. Meskipun mempunyai kualitas produk yang baik, hal tersebut belum tentu membuat konsumen puas. Kepuasan konsumen juga tergantung pada kualitas layanan yang ditawarkan oleh perusahaan.

Masalah kepuasan konsumen menjadi semakin kompleks karena perusahaan perlu memperhatikan aspek-aspek lain yang ada. Dimana Pada dasarnya tujuan dari suatu bisnis adalah untuk memperoleh laba yang besar dan juga menciptakan konsumen yang puas. Terciptanya kepuasan konsumen dapat memberikan beberapa manfaat, diantaranya hubungan antar perusahaan dan konsumen menjadi harmonis, terciptanya loyalitas konsumen, dan juga membentuk suatu rekomendasi. 


\section{B. Rumusan Masalah}

1. Bagaimana preferensi konsumen terhadap kepuasan konsumen ?

2. Bagaimana analisis kurva indeverensi terhadap kepuasan konsumen?

3. Bagaimana garis anggaran terhadap kepuasan konsumen ?

4. Bagaimana solusi optimal terhadap kepuasan konsumen?

5. Bagaimana prespektif Islam terhadap kepuasan konsumen ?

\section{Tujuan}

1. Untuk mengetahui preferensi konsumen terhadap kepuasan konsumen

2. Untuk mengetahui analisis kurva indeverensi terhadap kepuasan konsumen

3. Untuk mengetahui garis anggaran terhadap kepuasan konsumen

4. Untuk mengetahui solusi optimal terhadap kepuasan konsumen

5. Untuk mengetahui prespektif Islam terhadap kepuasan konsumen 


\section{BAB II \\ PEMBAHASAN}

\section{A. Landasan Teori}

\section{Pengertian Teori}

Teori merupakan seperangkat proposisi yang terintegrasi secara sintaksis (yaitu yang mengikuti aturan tertentu yang dapat dihubungkan secara logis atau dengan lainnya dengan data dasar yang dapat diamati) dan berfungsi sebagai wahana untuk meramalkan dan menjelaskan fenomena yang diamati. Teori tersusun dari asumsi, proposisi, dan aksioma dasar yang saling berkaitan, dan atau teorema (generalisasi yang diterima/terbukti secara empiris). ${ }^{1}$ Teori adalah serangkaian bagian atau variabel, definisi, dan dalil yang saling berhubungan yang menghadirkan sebuah pandangan sistematis mengenai fenomena dengan menentukan hubungan antar variabel, dengan menentukan hubungan antar variabel, dengan maksud menjelaskan fenomena alamiah. ${ }^{2}$

\section{Pengertian Kepuasan Konsumen}

Kepuasan atau satisfaction berasal dari bahasa latin "satis" (artinya cukup baik, memadai) dan "facio"(melakukan atau membuat). Secara sederhana kepuasan dapat di artikan sebagai upaya pemenuhan sesuatu atau membuat sesuatu memadai. Namun, di tinjau dari perspektif perilaku konsumen, istilah kepuasan konsumen lantas menjadi sesuatu yang kompleks. ${ }^{3}$

\footnotetext{
${ }^{1}$ Jusuf Soewadji, Pengantar Metodologi Penelitian, (Jakarta: Mitra Wacana Media, 2012), h. 107.

${ }^{2}$ Yulia Hafizah, 'Pengaruh Harga dan Kualitas Pelayanan Terhadap Kepuasan Konsumen", Jurnal Hasil Riset Januari (2020): h.1. 349.

${ }^{3}$ Fandy Tjiptono, Strategi Pemasaran, Cet. Ketiga (Jawa Timur: Banyumedia Publishing, 2007),
} 
Kotler mengatakan bahwa kepuasan konsumen adalah tingkat perasaan seseorang setelah membandingkan kinerja atau hasil yang ia rasakan dengan harapan. ${ }^{4}$ Sedangkan Richard F. Gerson mendefinisikan kepuasan konsumen sebagai persepsi konsumen bahwa harapannya telah terpenuhi atau terlampaui. ${ }^{5}$

Howard \& Sheth mengungkapkan bahwa kepuasan konsumen adalah situasi kognitif pembeli berkenaan dengan kesepadanan atau ketidaksepadanan antara hasil yang di dapatkan di bandingkan dengan pengorbanan yang di lakukan. ${ }^{6}$ Mowen merumuskan kepuasan konsumen sebagai sikap keseluruhan terhadap suatu barang atau jasa setelah perolehan (acquisition) dan pemakaiannya. Dengan kata lain, kepuasan konsumen merupakan penilaian evaluatif purnabeli yang di hasilkan dari seleksi pembelian spesifik. $^{7}$

\section{B. Pembahasan}

\section{Preferensi Konsumen}

Menurut Kotler preferensi konsumen menunjukkan kesukaan konsumen dari berbagai pilihan produk jasa yang ada. Preferensi merupakan kesukaan (kecenderungan hati) kepada sesuatu. ${ }^{8}$ Preferensi juga diartikan sebagai pilihan suka atau tidak suka oleh seseorang terhadap suatu produk, barang atau jasa yang dikonsumsi. Preferensi dapat diartikan suatu kecenderungan untuk memberikan perhatian kepada orang dan bertindak terhadap orang. Aktifitas atau situasi yang menjadi objek dari minat tersebut dengan disertai dengan perasaan senang atau puas. Sedangkan menurut Andi Mappiare definisi preferensi adalah suatu perangkat mental yang terdiri dari suatu campuran dari perasaan,

\section{6.}

${ }^{4}$ Philip Kotler, Manajemen Pemasaran, Jilid 1, Terj. Teguh hendra (Jakarta: Prenhalindo, 2002),

${ }^{5}$ Richard F. Gerson, Tingkat Kepasan Pelanggan, Terj. Widyaningrum (Jakarta: PPM, 2002), 3.

${ }^{6}$ Fandy Tjiptono, Pemasaran Jasa (Yogyakarta: Andi, 2014), 353.

${ }^{7}$ Basu Swasta Irawan, Manajemen Pemasaran Modern (Yogyakarta: Liberty, 2008), 119.

${ }^{8}$ Philip Kotler, Manajemen Pemasaran, Prehalindo, Jakarta, Cet Ke-10, 2000, h. 154. 
harapan, pendirian, prasangka, rasa takut atau kecenderungan lain yang mengarahkan individu kepada suatu piliha tertentu. Dalam kajian ekonomi, Ada empat prinsip pilihan rasional yaitu: ${ }^{9}$

\section{a) Kelengkapan ( Completeness )}

Prinsip ini mengatakan bahwa setiap individu selalu dapat menentukan keadaan mana yang lebih disukainya diantara dua keadaan. Konsumen dapat membandingkan dan menilai semua produk yang ada. Bila A dan B ialah dua keadaan produk yang berbeda, maka individu selalu dapat menentukan secara tepat satu diantara kemungkinan yang ada. Dengan kata lain, untuk setiap dua jenis produk A dan B, konsumen akan lebih suka A dari pada B, lebih suka B daripada A, suka akan keduaduanya, atau tidak suka akan kedua-duanya. Preferensi ini mengabaikan faktor biaya dalam mendapatkannya.

\section{b) Transivitas ( Transivity )}

Prinsip ini, menerangkan mengenai konsistensi seseorang dalam menentukan dan memutuskan pilihannya bila dihadapkan oleh beberapa alternatif pilihan produk. Dimana jika seorang individu mengatakan bahwa "produk A lebih disukai daripada produk B" dan "produk B lebih disukai daripada produk C", maka ia pasti akan mengatakan bahwa "produk A lebih disukai daripada produk C". Prinsip ini sebenarnya untuk memastikan adanya konsistensi internal di dalam diri individu dalam hal pengambil keputusan. Hal ini menunjukkan bahwa pada setiap alternatif pilihan seorang individu akan selalu konsisten dalam memutuskan preferensinya atas suatu produk dibandingkan dengan produk lain.

${ }^{9}$ Andi Mappiare, Psikologi Orang Dewasa Bagi Penyesuaian Dan Pendidikan, Surabaya, Usana Offsetprinting, 1994, h . 62. 
c) Kontinuitas (Continuity)

Prinsip ini menjelaskan bahwa jika seorang individu mengatakan "produk A lebih disukai daripada produk B”, maka setiap keadaan yang mendekati produk A pasti juga akan lebih disukai daripada produk B. jadi ada suatu kekonsistenan seorang konsumen dalam memilih suatu produk yang akan dikonsumsinya.

d) Lebih Banyak Lebih Baik ( The More Is The Better )

ini mejelaskan bahwa jumlah kepuasan akan meningkat, jika individu mengonsumsi lebih banyak barang atau produk tersebut. Sehingga konsumen cenderung akan selalu menambah konsumsinya demi kepuasan yang akan didapat.

Faktor yang Mempengaruhi Preferensi

Menurut Nur Rianto Al Arif, preferensi terhadap barang dan jasa dipengaruhi oleh empat faktor, yaitu: ${ }^{10}$

a) Faktor-faktor kebudayaan

1) Kebudayaan, Kebudayaan merupakan faktor penentu yang paling dasar dari keinginan dan perilaku seseorang. Bila makhluk-makhluk lainnya bertindak berdasarkan naluri, maka perilaku manusia umumnya dipelajari. Seorang anak yang sedang tumbuh mendapatkan seperangkat nilai, persepsi, preferensi dan perilaku melalui suatu proses sosialisasi yang melibatkan keluarga dan lembaga-lembaga sosial penting lainnya. Seorang anak yang dibesarkan di Amerika akan terbuka dengan nilai-nilai: prestasi dan keberhasilan, kegiatan efisiensi dan kepraktisan, kemajuan, kenyamanan di luar, kemanusiaan dan jiwa muda.

\footnotetext{
${ }^{10}$ Nur Rianto Al Arif, Teori Mikroekonomi, Kencana, Jakarta, 2010, h. 110
} 
2) Subbudaya, setiap kebudayaan terdiri dari subbudaya-subbudaya yang lebih kecil yang memberikan identifikasi dan sosialisasi yang lebih spesifik untuk para anggotanya. Subbudaya dapat dibedakan menjadi empat jenis: kelompok nasionalisme, kelompok keagamaan, kelompok ras, dan area geografis.

3) Kelas sosial, kelas-kelas sosial adalah kelompok yang relatif homogen dan bertahan lama dalam suatu masyarakat yang tersusun secara hierarki dan yang keanggotaannya mempunyai nilai, minat dan perilaku serupa.

b) Faktor-faktor sosial

1) Kelompok referensi, kelompok referensi seseorang terdiri dari seluruh kelompok yang mempunyai pengaruh langsung maupun tidak langsung terhadap sikap atau perilaku seseorang. Beberapa di antaranya kelompok primer, yang dengan adanya interaksi yang cukup berkesinambungan, seperti: keluarga, teman, tetangga dan teman sejawat. Kelompok sekunder, yang cenderung lebih resmi dan yang mana interaksi yang terjadi kurang berkisanambungan. Kelompok yang seseorang ingin menjadi anggotanya disebut kelompok aspirasi. Sebuah kelompok diasosiatif (memisahkan diri) adalah sebuah kelompok yang dinilai atau perilakunya tidak disukai oleh individu.

2) Keluarga, kita dapat membedakan dua keluarga dalam kehidupan pembeli, yang pertama ialah Keluarga orientasi, yang merupakan orang tua seseorang. Dari orang tualah seseorang mendapatkan pandangan tentang agama, politik, ekonomi dan merasakan ambisi pribadi nilai atau harga diri dan cinta. Keluarga prokreasi, yaitu pasangan hidup anak-anak seseorang keluarga merupakan organisasi pembeli yang konsumen yang paling penting dalam suatu masyarakat dan telah diteliti secara intensif. 
3) Peran dan Status, seseorang umumnya berpartisipasi dalam kelompok selama hidupnya keluarga, klub, organisasi. Posisi seseorang dalam setiap kelompok dapat di identifikasi dalam peran dan status.

c) Faktor Pribadi

1) Umur dan tahapan dalam siklus hidup, konsumsi seseorang juga dibentuk oleh tahapan siklus hidup keluarga. Beberapa penelitian terakhir telah mengidentifikasi tahapan-tahapan dalam siklus hidup psikologis. Orang-orang dewasa biasanya mengalami perubahan atau transformasi tertentu pada saat mereka menjalani hidupnya.

2) Pekerjaan, para pemasar berusaha mengidentifikasi kelompokkelompok pekerja yang memiliki minat diatas rata-rata, terhadap produk dan jasa tertentu.

3) Gaya hidup, gaya hidup seseorang adalah pola hidup didunia yang di ekspresikan oleh kegiatannya, minat dan pendapat seseorang. Gaya hidup menggambarkan “seseorang secara keseluruhan" yang berinteraksi dengan lingkungan. Gaya hidup juga mencerminkan sesuatu dibalik kelas sosial seseorang.

4) Kepribadian dan konsep diri, yang dimaksud dengan kepribadian adalah karakteristik psikologis yang berbeda dan setiap orang yang memandang responnya terhadap lingkungan yang relatif konsisten.

d) Faktor-Faktor Psikologis

1) Motivasi, beberapa kebutuhan biogenik, kebutuhan ini timbul dari suatu keadaan fisiologis tertentu, seperti: rasa lapar, haus, resah tidak nyaman. Adapun kebutuhan lain bersifat psikogenik, yaitu kebutuhan yang timbul dari keadaan fisiologis tertentu, seperti kebutuhan untuk diakui, kebutuhan harga diri atau kebutuhan diterima. Motivasi berasal 
dari bahasa latin movere yang artinya menggerakkan. Seorang konsumen tergerak membeli suatu produk karena ada sesuatu yang menggerakkan.

\section{Analisis Kurva Indeverensi}

Seorang konsumen yang pendapatannya terbatas, dapat memaksimumkan kepuasannya terhadap barang dan jasa yang menjadi preferensinya dengan memilih kombinasi konsumsi atas barang-barang yang dikonsumsi. Kombinasi konsumsi dua macam barang dari seorang konsumen yang memberikan tingkat kepuasan yang sama ditunjukkan dengan analisis kurva indifferen. Menurut Sadono Sukirno, Kurfa indefferen merupakan kurva yang menunjukkan kombinasi komsumsi/pembelian dua macam barang dari seorang konsumen yang memberikan tingkat kepuasan yang sama. ${ }^{11}$

Dengan analisis kurva indifferen konsumen tidak perlu mengetahui nilai guna (utility) secara absolut yang dapat diperoleh dari kombinasi tertentu dari kedua jenis barang tersebut. Ia hanya perlu membuat urutan preferensi yang lebih menguntungkan bagi dirinya dan tentunya urutan tersebut dibuat berdasarkan utilitasnya, sehingga kombinasi barang yang mempunyai nilai guna yang lebih tinggi akan lebih disukainya.

Dengan demikian tingkat kepuasan seseorang dalam mengonsumsi barang dan jasa tidak dapat dihitung dengan uang atau angka atau satuan lainnya, tetapi dapat dinyatakan lebih tinggi atau lebih rendah atau dengan skala ordinal seperti ke-1, ke-2, ke-3, dan seterusnya.

\footnotetext{
${ }^{11}$ Sadono Sukirno. 2008. Mikro Ekonomi Teori Pengantar. Jakarta: PT. Raja Grafindo Persada
} 


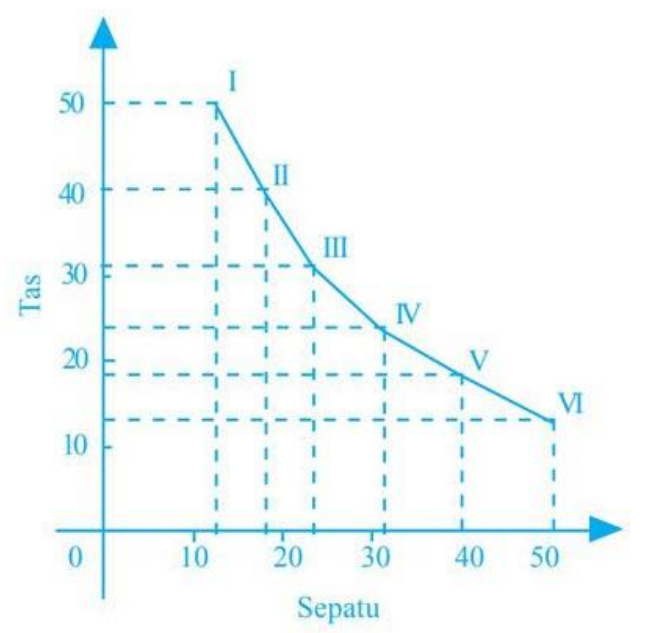

Perlu diketahui, bahwa dalam analisis kurva indifferen juga digunakan asumsiasumsi yang sama seperti pada marjinal utiliti. Berikut ini asumsi-asumsi yang digunakan dalam analisis kurva indifferen sebagai berikut $:^{12}$

- Rasionalitas, dengan dana dan harga pasar tertentu, konsumen dianggap selalu akan memilih kombinasi barang yang akan mendatangkan nilai guna atau kepuasan maksimum.

- Konsumen dianggap mempunyai informasi yang sempurna atas uang yang tersedia baginya serta informasi harga-harga yang ada di pasar.

- Konsumen perlu mempunyai preferensi yang disusun atas dasar besar kecilnya nilai guna, walaupun besarnya nilai guna itu sendiri secara absolut tidak perlu diketahui.

Sifat-Sifat Khusus Kurva Indifferen. Kurva indifferen mempunyai beberapa ciri atau sifat seperti berikut ini :

- Kurva indifferen mempunyai kemiringan (slope) negatif (miring dari kiri atas ke kanan bawah).

\footnotetext{
${ }^{12}$ Ari Sudarman. 1988. Teori Ekonomi Mikro. Yogyakarta: BPFE.anggota IKAPI
} 
- Kurva indifferen yang lebih tinggi kedudukannya menunjukkan tingkat kepuasan yang semakin tinggi.

- Kurva indifferen tidak pernah berpotongan dengan kurva indifferen lainnya.

- Kurva indifferen cembung ke titik asal (titik 0).

\section{Garis Anggaran}

Setiap konsumen berusaha mengalokasikan pendapatan yang terbatas untuk membeli berbagai macam komoditi yang tersedia sedemikian rupa sehingga tingkat kepuasan yang diterimanya maksimum. Kendala pendapatan ini juga dapat digambarkan pada bidang yang sama dengan kurva indiferen. Kendala pendapatan ini disebut juga garis anggaran (budget line), yaitu garis yang menghubungkan titik-titik kombinasi barang yang dapat dibeli dengan sejumlah pendapatan tertentu.

Misalnya pendapatan konsumen sebesar I, harga barang X adalah sebesar Px, dan harga barang Y adalah sebesar Py. Maka jumlah pembelian untuk X (Px. dikali X) dan untuk pembelian barang Y (Py dikali Y) tidak boleh lebih besar dari pendapatan yang tersedia. Atau secara matematis ditulis sebagai berikut

$$
\text { Px.X }+ \text { Py. Y } \leq \mathrm{I}
$$

Untuk mencari persamaan garis anggaran maka ketidaksamaan ini perlu di ubah dulu menjadi pertidaksamaan, yaitu menjadi ;

$$
\text { Px.X + Py.Y = I }
$$

Dari persamaan ini dapat ditentukan persamaan garis anggaran, yaitu membagi semua sisi dengan Py, sehingga didapat ; 


$$
\mathrm{Y}=(\mathrm{I} / \mathrm{Py}) \cdot(\mathrm{Px} / \mathrm{Py}) \cdot \mathrm{X}
$$

Di mana I/Py menunjukkan titik potong dengan sumbu vertikal, sedangkan (Px/Py) merupakan kemiringan (slope) garis anggaran. Perhatikan juga apabila Y tidak dibeli maka jumlah barang $\mathrm{X}$ yang dibeli adalah I/Px, yang merupakan titik potong dengan sumbu horizontal. Dalam bidang komoditi, garis anggaran ini dapat digambarkan sebagai berikut.

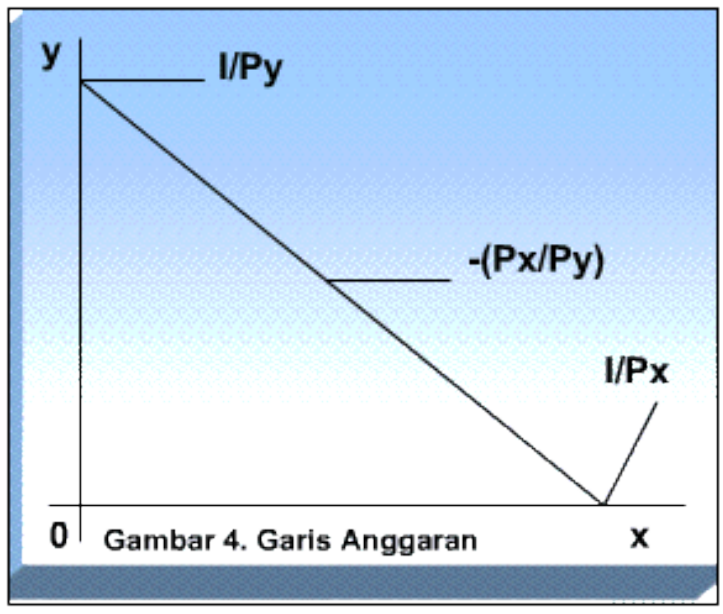

Menurut Said, Pergeseran garis anggaran dapat disebabkan oleh salah satu sebab berikut ini, yaitu : ${ }^{13}$

1) pertama perubahan harga $X$, sedangkan harga $Y$ dan pendapatan tetap. Apabila harga $\mathrm{X}$ turun maka semakin banyak jumlah barang $\mathrm{X}$ yang dapat dibeli, sehingga garis anggaran bergeser berlawanan arah dengan arah jarum jam. Sebaliknya kalau harga $\mathrm{X}$ naik maka semakin sedikit barang $\mathrm{X}$ yang dapat dibeli, dan pergeserannya adalah searah jarum jam.

\footnotetext{
${ }^{13}$ Said Kelana, Teori Ekonomi Mikro, RajaGrafindo Perkasa, Jakarta. [SKA Bab 4]
} 
2) kedua perubahan harga barang $Y$ dengan asumsi barang $X$ dan pendapatan tetap akan mengakibatkan pergeseran searah atau berlawanan arah jarum jam.

3) Ketiga terjadi perubahan harga barang dengan persentase yang sama, kalau harga $\mathrm{X}$ naik 10 persen dan harga $\mathrm{Y}$ juga naik 10 persen, atau bila $\mathrm{Y}$ turun 10 persen dan harga $\mathrm{X}$ juga turun 10 persen. Perubahan ini akan menyebabkan garis anggaran bergeser sejajar ke kiri atau ke kanan.

4) Keempat, Perubahan garis anggaran ke kiri atau ke kanan dapat juga disebabkan oleh kenaikan pendapatan. Apabila pendapatan naik sedangkan harga kedua jenis barang konstan maka garis anggaran akan bergeser ke kanan, ini berarti lebih banyak dari kedua jenis barang yang dapat dibeli. Sedangkan, kalau terjadi penurunan pendapatan akan menyebabkan garis anggaran bergeser ke kiri secara sejajar.

\section{Solusi Optimal}

Kombinasi konsumsi yang dapat memberikan kepuasan konsumen secara maksimal yang merupakan optimalitas atau titik optimal bagi konsumen. Untuk mencapai tingkat optimalisasi konsumen, seorang konsumen dibatasi oleh garis anggaran dari pendapatannya atau berbagai komoditas yang dapat dibelinya. Dengan demikian, kepuasaan maksimum seorang konsumen terjadi pada titik dimana terjadi persinggungan antara kurva indifference dengan budget line. Konsumen akan memaksimalkan pilihannya dengan dua cara:

1) Memaksimalkan utility function pada budget line tertentu

Maksimalisasi utility function pada budget tertentu 


\begin{tabular}{|c|c|c|c|}
\hline Kombinasi Barang & $\begin{array}{l}\text { Jumlah Barang X } \\
\text { Yamg dikomsumsi }\end{array}$ & $\begin{array}{l}\text { Jumlah Barang Y } \\
\text { yang dikomsumsi }\end{array}$ & Pengeluaran Total \\
\hline B & 20 & 30 & $\$ 80$ \\
\hline R & 20 & 20 & $\$ 60$ \\
\hline S & 10 & 30 & $\$ 70$ \\
\hline
\end{tabular}

Dengan tingkat pengeluaran tertentu yaitu $\$ 80$, maka kombinasi barang B lebih baik daripada kombinasi $\mathrm{R}$ dan $\mathrm{S}$. Kombinasi $\mathrm{B}$ lebih baik daripada $\mathrm{R}$, karena dapat mengkonsumsi barang Y lebih banyak; dari segi total pengeluaran pun terlihat bahwa masih ada yang tidak termanfaatkan sebesar \$20. Kombinasi B lebih baik daripada kombinasi S, karena dapat mengonsumsi barang $\mathrm{X}$ lebih banyak; dari segi total pengeluaran pun terlihat bahwa masih ada yang tidak termanfaatkan sebesar $\$ 10$.

2) Meminimalkan budget line pada utility function tertentu

\begin{tabular}{|c|c|c|c|}
\hline Kombinasi Barang & Jumlah Barang X & Jumlah Barang Y & Pengeluaran Total \\
& yang Dikomsumsi & yang Dikomsumsi & \\
\hline B & 20 & 30 & $\$ 80$ \\
\hline T & 20 & 30 & $\$ 90$ \\
\hline
\end{tabular}

Untuk mengonsumsi $20 \mathrm{X}$ dan $30 \mathrm{Y}$ cukup diperlukan uang $\$ 80$. Oleh karenanya kombinasi $\mathrm{B}$ lebih baik daripada kombinasi $\mathrm{T}$, karena untuk mendapatkan $\mathrm{T}$ ia harus membayar lebih mahal untuk jumlah barang yang sama.

Untuk mengonsumsi barang $\mathrm{x}$ dan y dengan tingkat kepuasan yang sama, seorang konsumen mempunyai beberapa alternatif garis anggaran yang dibutuhkan. Dengan 
demikian, optimalisasi konsumen akan terbentuk pada budget line paling kecil untuk mendapatkan kepuasan yang sama.

\section{Prespektif Islam Terhadap Kepuasan Konsumen}

Lahirnya teori kepuasan konsumen dalam perspektif ekonomi konvensional akan melahirkan manusia serakah dan mementingkan diri sendiri. Hal ini karena asumsi rasional konsumsi dibangun atas dasar utility (kepuasan). Secara sederhana setidaknya ada dua hal yang perlu untuk kritis dari perilaku konsumsi yang beroriental pada utility yakni pertama tujuan konsumsi hanyalah untuk mencapai kepuasan dan kedua batasan konsumsi hanyalah kemampuan anggaran. Artinya sepanjang dia mempunyai pendapat maka tidak ada yang bisa membatasinya untuk melakukan konsumsi. Tentunya sikap ini akan menafikan kepentingan orang lain dan menafikan zat dan jenis barang (halal dan berkahnya barang).

Dalam menentukan kepuasan konsumsi bagi seorang muslim harus berorientasi dalam mengoptimalkan maslahah bukan memaksimalkan. Karena dalam rasionalitas islam menganggap prinsip lebih banyak tidak selalu lebih baik (the more isn't always the better). Maslahah akan terwujud ketika nilai berkah optimum dapat terpenuhi. Oleh karena itu kandungan berkah sangat mempengaruhi preferensi konsumen pada saat akan mengonsumsi barang. Hal ini menjadikan konsumen akan selalu mengoptimalkan berkah dalam usaha mengoptimalkan maslahah. ${ }^{14}$

Dalam ilmu ekonomi Islam, kepuasan seorang muslim disebut dengan qona'ah. Kepuasan dalam Islam (qona'ah) merupakan cerminan kepuasan seseorang baik secara batiniah maupun lahiriah. Kepuasan dalam Islam berkaitan dengan

\footnotetext{
${ }^{14}$ Sumarlin, Ekonomi Islam Sebuah Pendekatan Ekonomi Mikro Perpektif Islam, (Yogyakarta: Graha Ilmu, 2013), h. 100-103
} 
keimanan yang melahirkan rasa syukur. Kepuasan menurut Islam harus mempertimbangkan beberapa hal berikut: Barang atau jasa yang dikonsumsi harus halal, dalam mengonsumsi barang atau jasa tidak berlebihlebihan dan Tidak mengandung riba. ${ }^{15}$

Dimensi reliable (kehandalan) yang berkenaan dengan kemampuan untuk memberikan jasa yang dijanjikan secara terpercaya dan akurat. Pelayanan akan dapat dikatakan reliabel apabila dalam perjanjian yang telah diungkapkan dicapai secara akurat.

Dimensi responsiveness (daya tanggap) berkenaan dengan kesediaan atau kemauan pegawai dalam memberikan pelayanan yang cepat dan tepat kepada konsumen. Kecepatan dan ketepatan pelayanan berkenaan dengan profesionalitas. Dalam arti seorang pegawai yang profesional dirinya akan dapat memberikan pelayanan secara tepat dan cepat. Profesionalitas ini yang ditunjukkan melalui kemampuannya dalam memberikan pelayanan kepada konsumen. Dalam pelaksanaan suatu pekerjaan, seorang dikatakan profesional apabila dirinya bekerja sesuai dengan keahlian atau kemampuannya. Pekerjaan akan dapat dilakukan dan diselesaikan dengan baik secara cepat dan tepat apabila dilakukan oleh orang yang memiliki kemampuan sesuai dengan bidang pekerjaannya. Kepercayaan yang diberikan konsumen merupakan suatu amanat. Apabila amanat tersebut disia-siakan akan berdampak pada ketidakberhasilan dan kehancuran lembaga dalam memberikan pelayanan kepada konsumen. Untuk itu kepercayaan konsumen sebagai suatu amanat hendaknya tidak disia-siakan dengan memberikan pelayanan secara profesional melalui pegawai yang bekerja sesuai dengan

\footnotetext{
${ }^{15}$ Fitria Salahika Salma, Ririn Tri Ratnasari, Pengaruh Kualitas Jasa Perpektif Islam Terhadap Kepuasan dan Loyalitas Pelanggan Hotel Grand Kalimas di Surabaya(Jestt, Vol. 2 No. 4 April 2015) h. 327
} 
bidangnya dan mengerjakan pekerjaannya secara cepat dan tepat, sebagaimana yang dinyatakan dalam hadis Rasulullah SAW diriwayatkan oleh Bukhari, yaitu: "apabila amanat disia-siakan, maka tunggulah kehancurannya, berkata seseorang: bagaimana caranya menyia-nyiakan amanat ya Rasulullah? Berkata Nabi: apabila diserahkan sesuatu pekerjaan kepada yang bukan ahlinya, maka tunggulah kehancurannya”.

Dimensi assurance (jaminan) berkenaan dengan pengetahuan atau wawasan, kesopanan, santun, kepercayaan diri dari pemberi layanan, serta respek terhadap konsumen. Apabila pemberi layanan menunjukkan sikap respek, sopan santun dan kelemahlembutan maka akan meningkatkan persepsi positif dan nilai bagi konsumen terhadap lembaga penyedia jasa. Assurance ini akan meningkatkan kepercayaan, rasa aman, bebas dari resiko atau bahaya, sehingga membuat konsumen merasakan kepuasan dan akan loyal terhadap lembaga penyedia layanan. Baik buruknya layanan yang diberikan akan menentukan keberhasilan lembaga atau perusahaan pemberi jasa layanan. Dengan memberian pelayanan yang menunjukkan kesopanan dan kelemahlembutan akan menjadi jaminan rasa aman bagi konsumen dan yang berdampak pada kesuksesan lembaga penyedia layanan jasa.

Dimensi empathy (empati) berkenaan dengan kemauan pegawai untuk peduli dan memberi perhatian secara individu kepada konsumen. Kemauan ini yang ditunjukkan melalui hubungan, komunikasi, memahami dan perhatian terhadap kebutuhan serta keluhan konsumen. Perwujudan dari sikap empati ini akan membuat konsumen merasa kebutuhannya terpuaskan karena dirinya dilayani dengan baik. Sikap empati pegawai ini ditunjukkan melalui pemberian layanan informasi dan keluhan konsumen, melayani transaksi konsumen dengan senang hati, membantu konsumen ketika dirinya mengalami kesulitan dalam bertransaksi atau hal lainnya berkenaan 
dengan pelayanan lembaga. Kediaan memberikan perhatian dan membantu akan meningkatkan persepsi dan sikap positif konsumen terhadap layanan lembaga. Hal ini yang akan mendatangkan kesukaan, kepuasan dan meningkatkan loyalitas konsumen. Berkenaan dengan empati, dalam Rasullulah saw yang diriwayatkan oleh Bukhori Muslim, menyatakan: “Abu Musa al-Asy'ary ra. Berkata: bersabda Nabi saw, "seorang muslim yang menjadi bendahara (kasir) yang amanat, yang melaksanakan apa-apa yang diperintahkan kepadanya dengan sempurna dan suka hati, memberikannya kepada siapa yang diperintahkan memberikannya, maka bendahara itu termasuk salah seorang yang mendapat pahala bersedekah".

Dimensi tangibles (bukti fisik) dapat berupa fasilitas fisik seperti gedung, ruangan yang nyaman, dan sarana prasarana lainnya. Dalam konsep Islam pelayanan yang berkenaan dengan tampilan fisik hendaknya tidak menunjukkan kemewahan. Fasilitas yang membuat konsumen merasa nyaman memang penting, namun bukanlah fasilitas yang menonjolkan kemewahan. Pernyataan ini sebagaimana yang dinyatakan dalam Al Qur'an surat AtTakaatsur ayat 1-5, yaitu: "Bermegah-megahan telah melalaikan kamu, sampai kamu masuk kedalam kubur. Janganlah begitu, kelak kamu akan mengetahui (akibat perbuatanmu itu) dan janganlah begitu, kelak kamu akan mengetahui. Janganlah begitu,jika kamu mengetahui dengan pengetahuan yang yakin”.

Berdasarkan teori-teori yang telah diungkapkan, maka disimpulkan bahwa yang dimaksud dengan kualitas pelayanan adalah suatu penilaian konsumen tentang kesesuaian tingkat pelayanan yang diberikan dengan tingkat pelayanan yang diharapkannya. Kualitas pelayanan ini diukur dengan lima dimensi, yaitu: 1) Reliability (Kehandalan), 2) Responsiveness (Daya Tanggap), 3) Assurance (Keyakinan), 4) Emphaty (Empati) dan 5) Tangibles (Bukti Fisik). 
Dalam ekonomi islam kepuasan dikenal dengan maslahah, dengan pengertian tepenuhi kebutuhan baik bersifat fisik maupun spiritual. Islam sangat mementingkan keseimbangan kebutuhan fisik dan nonfisik yang didasarkan atas nilainilai syariah. Seorang muslim untukmencapai tingkat kepuasan harus mempertimbangkan beberapa hal,yaitu barang yang dikonsumsi adalah halal, baik secara dzatnya maupun secara memperolehnya, tidak bersikap isrof (royal) dan tabzir (sia-sia). Oleh karena itu, kepuasan seorang muslim tidak didasarkan banyak sedikitnya barang yang dikonsumsi, tetapi didasarkan atasberapa besar nilai ibadah yang didapatkan dari yang dikonsumsinya.

Dalam perspektif Islam, yang menjadi tolok ukur dalam menilai kepuasan pelanggan adalah standar syariah. Kepuasan pelanggan dalam pandangan syariah adalah tingkat perbandingan antara harapan terhadap produk atau jasa yang seharusnya sesuai syariah dengan kenyataan yang diterima.

Menurut pendapat Qardhawi (1997), sebagai pedoman untuk mengetahui tingkat kepuasan yang dirasakan oleh konsumen, maka sebuah perusahaan barang maupun jasa harus melihat kinerja perusahaannya yang berkaitan dengan: ${ }^{16}$

\section{a. Sifat Jujur}

Sebuah perusahaan harus menanamkan sifat jujur kepada seluruh personel yang terlibat dalam perusahaan tersebut. Hal ini berdasarkan pada sabda Nabi SAW, yang artinya : "Muslim itu adalah saudara muslim. Tidak boleh bagi seorang

\footnotetext{
${ }^{16}$ Wahyuni, R. A. (2019). Perkembangan Ekonomi Islam Di Indonesia Melalui Penyelenggaraan. Jurnal Kajian Hukum Islam, 4(2), 184-192.
} 
muslim, apabila ia berdagang dengan saudaranya dan menemukan cacat, kecuali diterangkannya." (HR. Ahmad dan Thobrani).

\section{b. Sifat Amanah}

Amanah adalah mengembalikan hak apa saja kepada pemiliknya, tidak mengambil sesuatu melebihi haknya dan tidak mengurangi hak orang lain, baik berupa harga ataupun yang lainnya. Dalam berdagang dikenal istilah "menjual dengan amanah", artinya penjual menjelaskan ciri-ciri, kualitas dan harga barang dagangan kepada pembeli tanpa melebih-lebihkannya. Berdasarkan uraian tersebut, maka sebuah perusahaan memberikan pelayanan yang memuaskan kepada pelanggan, antara lain dengan cara menjelaskan apa saja yang berkaitan dengan barang atau jasa yang akan dijualnya kepada pelanggan. Dengan demikian konsumen dapat mengerti dan tidak ragu dalam memilih barang atau jasa tersebut.

\section{c. Benar}

Berdusta dalam berdagang sangat dikecam dalam Islam, terlebih lagi jika disertai dengan sumpah palsu atas Hamba Allah. Dalam hadits mutafaq'alaih dari hakim bin Hazm yang artinya : "Penjual dan pembeli bebas memilih selama belum putus transaksi, jika keduanya bersikap benar dan menjelaskan kekurangan barang yang diperdagangkan maka keduanya mendapatkan berkah dari jual belinya. Namun, jika keduanya saling menutupi aib barang dagangan itu dan berbohong maka jika mereka mendapatkan laba, hilanglah berkah jual beli itu.

Ilmu ekonomi adalah pengetahuan dan aplikasi dari ajaran dan aturan syariah yang mencegah ketidakadilan dalam memperoleh sumber-sumber daya material memenuhi kebutuhan manusia yang memungkinkan untuk melaksanakan kawajiban 
kepada Allah dan masyarakat. ${ }^{17}$ Kepuasan merupakan suatu akibat terpenuhinya suatu keinginan, sedangkan maslahah merupakan suatu akibat atasterpenuhinya suatu kebutuhan atau fitrah. Meskipun demikian, terpenhinya suatu kebutuhan juga akan memberikan kepuasan terutama jika kebutuhan tersebut disadari dan diinginkan. ${ }^{18}$

Ekonomi Islam konsumen dalam memenuhi kebutuhannya cenderung untuk memilih barang dan jasa yang memberikan maslahah maksimum. Kecenderungan memilih ditentukan oleh kebutuhan dan keinginan. ${ }^{19}$

Dari uraian diatas ditarik kesimpulan bahwa kepuasan konsumen menurut ekonomi Islam berkaitan erat dengan kebutuhan, keinginan, maslahah, manfaat, berkah, keyakinan dan kehalalan. Dalam ekonomi Islam kepuasan dikenal dengan istilah maslahah dengan pengertian terpenuhi kebutuhan baik fisik maupun spiritual. Islam sangat mementingkan keseimbangan kebutuhan fisik dan non fisik yang didasarkan atas nilai-nilai syariah. Seorang muslim untuk mencapai tingakat kepuasan harus mempertimbangkan beberapa hal yaitu barang yang dikonsumsi adalah halal, baik secara dzatnya maupun cara memperolehnya, tidak bersifat isrof (royal) atau tabzir (siasia). Oleh karena itu kepuasan seorang muslim tidak didasarkan banyak sedikitnya barang yang dikonsumsi, tetapi didasarkan atas seberapa besar nilai ibadah yang didapat dari yang dikonsumsinya.

Adapun prinsip-prinsip ekonomi Islam adalah sebagai berikut:

\footnotetext{
${ }^{17}$ Rozalinda, Ekonomi Islam : Teori dan Aplikasinya Pada Aktifitas Ekonomi, ( Jakarta: Rajawali Pers, 2014), h.2-3

${ }^{18}$ Zaki Fuas Chalil, Pemerataan Distribusi Kekayaan dalam Ekonomi Islam, (Yogyakarta: Erlangga, 2016), h.132

${ }_{19}$ Pusat Pengkajian dan Pengembangan Ekonomi Islam (P3EI) Universitas Islam Indonesia Yogyakarta Atas Kerjasama dengan Bank Indonesia dan Ekonomi Islam, (Jakarta: PT Raja Grapindo, 2014),h.28
} 
a) Tauhid, merupakan fondasi ajaran Islam. Dengan tauhid manusia menyaksikan bahwa tiada satupun yang layak disembah selain Allah dan tidak ada pemilik langit, bumi dan segala isinya selain Allah daripada Allah.

b) Adl, Allah adalah pencipta segala sesuatu dan salah satu sifatnya adalah adil. Dia tidak membeda-bedakan perilaku terhadap makluk-Nya secara zalim.

c) Akhlak, prinsip ini merupakan petunjuk dari pengalaman sifatsifat utama yang dimiliki oleh Nabi dan Rasulnya, dalam sebuah kegiatan ekonomi, yaitu: Shidiq (jujur), Tabligh (menyampaikan kebenaran), Amanah (dapat dipercaya), Fathanah (cerdik bijaksana).

d) Keseimbangan. Allah telah menyediakan apa yang ada dilngit dan dibumi untuk kebahagiaan hidup manusia dengan batas-batas tertentu, seperti tidak boleh melakukan perbuatan yang membahayakan keselamatan lahir dan batin, diri sendiri ataupun orang lain dan lingkungan sekitar.

e) Kebebasan individu. Kebebasan ekonomi adalah tiang utama dalam struktur ekonomi Islam, karena kebebasan ekonomi bagi setiap individu akan menciptakan mekanisme pasar dalam perekonomian yang bersendikan keadilan.

Perilaku konsumen Islam didasarkan atas rasionalitas yang disempurnakan dan mengintegrasikan keyakinan dan kebenaran yang melampaui rasionalitas manusia yang sangat terbatas berdasarkan Alquran dan sunnah. Islam memberikan konsep pemenuhan kebutuhan disertai kekuatan moral, ketiadaan tekanan batin dan adanya keharmonisan antar sesama. Ekonomi Islam bukan hanya berbicara tentang pemuasan materi yang bersifat fisik, tapi juga berbicara cukup luas tentang 
pemuasan materi yang bersifat abstrak, pemuasan yang lebih berkaitan dengan posisi manusia sebagai hamba Allah Swt. ${ }^{20}$

Prinsip-prinsip dasar perilaku konsumen Islam diantaranya:

1) Prinsip syariah yaitu menyangkut dasar syariat yang harus terpenuhi dalam melakukan konsumsi dimana terdiri dari prindip akidah, yaitu hakikat konsumsi adalah sebagai sarana untuk ketaatan untuk ibadah sebagai perwujudan keyakinan manusia sebagai makhluk dan khalifah yang nantinya diminta pertanggung jawaban oleh pencipta. Prinsip ilmu yaitu seseorang ketika akan mengkonsumsi harus mengetahui ilmu tentang barang yang akan dikonsumsi dan hukum-hukum yang berkaitan dengannya apakah merupakan sesuatu yang halal atau haram baik ditinjau dari zat, proses maupun tujuannya. Dan prinsip amaliyah, sebagai kosekuensi akidah dan ilmu yang telah diketahui tentang konsumsi Islam tersebut, seseorang dituntut untuk menjalankan apa yang sudah diketahui, maka dia akan mengkonsumsi hanya yang halal serta menjauhi yang haram dan syubhat.

2) Prinsip kualitas, yaitu sesuai dengan batas batas kualitas yang telah dijelaskan dalam syariat Islam. Salah satu bentuk prinsip kualitas ini adalah kesederhanaan, yaitu mengkonsumsi secara proposional tanpa menghamburkan harta, bermewah-mewah, mubazir, namun tidak juga pelit. Menyesuaikan antara pemasukan dan pengeluaran juga merupakan perwujudan prinsip kualitas dalam konsumsi. Artinya dalam mengkonsumsi harus disesuaikan dengan kemampuan yang dimilikinya, bukan

\footnotetext{
${ }^{20}$ Adiwarman Karim, Ekonomi Mikro Islam.....h.76
} 
besar pasak daripada tiang. Selain itu, bentuk prinsip kualitas lainya adalah menabung dan investasi, artinya tidak semua kekayaan digunakan untuk konsumsi tapi juga disimpan untung kepentingan pengembangan kekayaan itu sendiri. ${ }^{21}$

3) Prinsip prioritas yaitu memperhatikan urutan kepentingan yang harus diprioritaskan agar tidak terjadi kemudharatan, yaitu:

a) Primer, adalah konsumsi dasar yang haruss terpenuhi agar manusia dapat hidup dan menegakkan kemaslahatan dirinya dunia dan agamanya serta orang terdekatnya, seperti makanan pokok.

b) Skunder, yaitu konsumsi untuk menambah attau meningkatkan tingkat kualitas hidup yang baik, jika tidak terpenuhi maka manusia akan mengalami kesusahan.

c) Tersier yaitu, konsumsi pelengkap manusia.

4) Prinsip sosial, yaitu memperhatikan lingkungan sosial disekitarnya sehingga tercipta keharmonisan hidup dalam masyarakat, diantaranya: kepentingan uuamat, yaitu saling menanggung dan menolong sehingga Islam mewajibkan zakat bagi yang mampu juga menganjurkan shadaqah, infak dan wakaf.

a) Keteladanan, yaitu memberikan contoh yang baik dalam berkonsumsi baik dala keluarga maupun masyarakat.

b) Tidak membahayakan atau merugikan diri sendiri dalam mengkonsumsi sehingga tidak menimbulkan kemudharatan seperti mabuk-mabukan, merokok dan sebagainta.

c) Kaidah lingkungan yaitu, dalam mengkonsumsi harus sesuai dengan kondisi potensi daya dukuung sumber daya alam dan berkelanjutan atau tidak merusak lingkungan.

\footnotetext{
${ }^{21}$ Lukman Hakim, Prinsip-prinsip Ekonomi Islam (Surakarta :Erlangga,2017), h. 95
} 
Seorang muslim, dalam penggunaan penghasilan memiliki dua sisi, yaitu pertama untuk memenuhi kebutuhan diri dan kelurganya dan sebagaiannya lagi untuk dibelanjakan di jalan Allah. 


\section{BAB III}

\section{PENUTUP}

\section{A. Kesimpulan}

- Kepuasan atau satisfaction berasal dari bahasa latin "satis" (artinya cukup baik, memadai) dan "facio"(melakukan atau membuat). Secara sederhana kepuasan dapat di artikan sebagai upaya pemenuhan sesuatu atau membuat sesuatu memadai. Namun, di tinjau dari perspektif perilaku konsumen, istilah kepuasan konsumen lantas menjadi sesuatu yang kompleks

- Preferensi konsumen menunjukkan kesukaan konsumen dari berbagai pilihan produk jasa yang ada. Preferensi merupakan kesukaan (kecenderungan hati) kepada sesuatu. Preferensi juga diartikan sebagai pilihan suka atau tidak suka oleh seseorang terhadap suatu produk, barang atau jasa yang dikonsumsi. Preferensi dapat diartikan suatu kecenderungan untuk memberikan perhatian kepada orang dan bertindak terhadap orang. Aktifitas atau situasi yang menjadi objek dari minat tersebut dengan disertai dengan perasaan senang atau puas. Kurva indefferen merupakan kurva yang menunjukkan kombinasi komsumsi/pembelian dua macam barang dari seorang konsumen yang memberikan tingkat kepuasan yang sama. Dengan analisis kurva indifferen konsumen tidak perlu mengetahui nilai guna (utility) secara absolut yang dapat diperoleh dari kombinasi tertentu dari kedua jenis barang tersebut. Ia hanya perlu membuat urutan preferensi yang lebih menguntungkan bagi dirinya dan tentunya urutan tersebut dibuat berdasarkan utilitasnya, sehingga kombinasi barang yang mempunyai nilai guna yang lebih tinggi akan lebih disukainya. 
- Garis anggaran (budget line), yaitu garis yang menghubungkan titik-titik kombinasi barang yang dapat dibeli dengan sejumlah pendapatan tertentu.

- Kombinasi konsumsi yang dapat memberikan kepuasan konsumen secara maksimal yang merupakan optimalitas atau titik optimal bagi konsumen. Untuk mencapai tingkat optimalisasi konsumen, seorang konsumen dibatasi oleh garis anggaran dari pendapatannya atau berbagai komoditas yang dapat dibelinya.

- Dalam ilmu ekonomi Islam, kepuasan seorang muslim disebut dengan qona'ah. Kepuasan dalam Islam (qona'ah) merupakan cerminan kepuasan seseorang baik secara batiniah maupun lahiriah. Kepuasan dalam Islam berkaitan dengan keimanan yang melahirkan rasa syukur. Kepuasan menurut Islam harus mempertimbangkan beberapa hal berikut: Barang atau jasa yang dikonsumsi harus halal, dalam mengonsumsi barang atau jasa tidak berlebihlebihan dan Tidak mengandung riba.

\section{B. Saran}

Setelah saya menyelesaikan makalah ini, menurut saya Teori Kepuasan Konsumen, sangat memerlukan berbagai penilaian dalam aspek-aspeknya, agar perubahan yang terjadi nantinya bisa kita hadapi dengan lebih baik lagi. Kita tentu dapat menerapkan nilai - nilai keislaman dalam pengembangan perekonomian, serta Indonesia bisa semakin maju dalam pengembangan perekonomian yang berbasisi keislaman. saya sangat yakin dan percaya, bahwa Indonesia bisa menghadapi perkembangan tersebut dan akan memiliki kehidupan berbangsa yang lebih baik lagi bagi masyarakatnya. 


\section{DAFTAR PUSTAKA}

Arif, N. R. (2010). Teori Mikroekonomi. Jakarta: Kencana.

Chalil, Z. F. (2016). Pemerataan Distribusi Kekayaan dalam Ekonomi Islam. Yogyakarta: Erlangga.

Gerson, R. F. (2002). Tingkat Kepasan Pelanggan. Jakarta: PPM.

Hafizah, Y. (2020). Pengaruh Harga dan Kualitas Pelayanan Terhadap Kepuasan Konsumen. Jurnal Hasil Riset, 1.

Hakim, L. (2017). Prinsip-prinsip Ekonomi Islam. Surakarta: Erlangga.

Irawan, B. S. (2008). Manajemen Pemasaran Modern. Yogyakarta: Liberty.

Karim, A. A. (2012). Ekonomi Mikro Islam. Jakarta: Rajawali Pers.

Kelana, S. (t.thn.). Teori Ekonomi Mikro (SKA Bab 4 ed.). Jakarta: RajaGrafindo Perkasa.

kepuasan-pelanggan-dalamprespektif.html. $(2015,03)$. Retrieved from tipsserbaserbi.blogspot.com.

Kotler, P. (2000). Manajemen Pemasaran (10 ed.). Jakarta: Prehalindo.

Kotler, P. (2002). Manajemen Pemasaran. Jakarta: Prenhalindo.

Mappiare, A. (1994). Psikologi Orang Dewasa Bagi Penyesuaian Dan Pendidikan. Surabaya: Usana Offsetprinting.

Pusat Pengkajian dan Pengembangan Ekonomi Islam (P3EI) Universitas Islam Indonesia Yogyakarta Atas Kerjasama dengan Bank Indonesia dan Ekonomi Islam. (2014). Jakarta: PT Raja Grapindo.

Rozalinda. (2015). Ekonomi Islam Teori Dan Aplikasinya pada Aktivitas Ekonomi. Jakarta: Rajawali Pers.

Salma, F. S., \& Ratnasari, R. T. (2015). Pengaruh Kualitas Jasa Perpektif Islam Terhadap Kepuasan dan Loyalitas Pelanggan Hotel Grand Kalimas di Surabaya. Jesst, 2(4), 327.

Soewadji, J. (2012). Pengantar Metodologi Penelitian. Jakarta: Mitra Wacana Media.

Sudarman, A. (1988). Teori Ekonomi Mikro. Yogyakarta: BPFE.anggota IKAPI.

Sukirno, S. (2008). Mikro Ekonomi Teori Pengantar. Jakarta: PT. Raja Grafindo Persada.

Sumarlin. (2013). Ekonomi Islam Sebuah Pendekatan Ekonomi Mikro Perpektif Islam. Yogyakarta: Grahah Ilmu.

Tjiptono, F. (2007). Strategi Pemasaran. Jawa Timur: Banyumedia Publishing.

Tjiptono, F. (2014). Pemasaran Jasa. Yogyakarta: Andi. 
Wahyuni, R. A. (2019). Perkembangan Ekonomi Islam Di Indonesia Melalui Penyelenggaraan. Jurnal Kajian Hukum Islam, 4(2), 184-192. 